\section{Original researches}

Received: 29 May 2020

Revised: 08 June 2020

Accepted: 09 June 2020

Oles Gonchar Dnipro National University, Gagarin Av., 72, Dnipro, 49000, Ukraine

Bogdan Khmelnitsky Melitopol State Pedagogical University, Hetmanska st., 20, Melitopol, 72318, Ukraine

Tel.: +38-056-374-98-22

E-mail: kunah_olga@ukr.net nadyayork777@gmail.com

Cite this article: Kunakh, O. M., Yorkina, N. V., Zhukova, Y. O., \& Malasay, A. S. (2020). Environmental impact assessment: possible application of the ecomorphic approach. Agrology, 3(3), 133-144. doi: 10.32819/020016

\title{
Environmental Impact Assessment: Possible Application of the Ecomorphic Approach
}

\author{
O. M. Kunakh ${ }^{1}$, N. V. Yorkina ${ }^{2}$, Y. O. Zhukova ${ }^{1}$, A. S. Malasay ${ }^{1}$ \\ ${ }^{1}$ Oles Gonchar Dnipro National University, Dnipro, Ukraine \\ ${ }^{2}$ Bogdan Khmelnitsky Melitopol State Pedagogical University, Melitopol, Ukraine
}

\begin{abstract}
Environmental impact assessment (EIA) is a process by which environmental impact information is collected and precautions are determined. In many EIA countries, it is enshrined legislatively, but there is a common problem - in practice, many elements of the procedure are performed at a sub-standardized level. Scientists and practitioners note the problematic nature of the effectiveness of EIA procedures, which is primarily caused by the difficulties of turning assessments of biological diversity into clear management decisions. Biodiversity assessment and monitoring programs should consist of a list of protocols that ap-ply reliable methods of accounting for living organisms, taking into account spa-tial and time context. It is particularly noted that without "scientific rigor" and methodology of evaluation, the collected data may not matter for decision-making and represent wasted time and money. The effectiveness of EIA procedures can be improved by incorporating ecosystem services into the concept procedure, as it is a reflection of the functioning of ecosystems, which is a prerequisite for the socio-economic wellbeing of the population. One of the markers of ecosystem services is the ecomorphic structure of living cover. The investigation revealed the role of the ecomorphic structure of the soil macrofauna community as an indicator of the level of anthropogenic effects on the ecosystem. The results indicate that the ecomorphic characteristics of the soil macrofauna community are informative markers of the state of the ecosystem. The soil macrofauna community is divided into functional groups, which should be considered as a mechanism to maintain the stability of the ecosystem as a whole. This structuring has a place in both ecological and geographical space. Comparing grouping projections in both of these spaces provides an opportunity to interpret functional groups. It is important to note that both natural and anthropogenic factors structurally affect soil macrofaunf. An important aspect of anthropogenic influence is the inhibition of the endogeic block of the soil macrofauna community. Functionally, it is replaced by an epigeic macrofauna, which is represented by extremely mobile species capable of recolonizing microsites with a temporary reduction in anthropogenic pressure. Thus, the ecomorphic structure of the soil macrofauna community has a high potential for application in the system of environmental impact assessment tools.
\end{abstract}

Keywords: anthropogenic impact; biodiversity; soil biota; environment factors; ecological niche; soil macrofauna.

\section{Introduction}

Environmental impact assessment (EIA) is the process by which information on environmental impact is collected and preventive actions are identified. In many countries, EIA is legally enshrined, but there is a common problem - in practice many elements of the procedure are performed at a substandardized level (Nita, 2019). Scientists and practitioners note the problematic nature of the effectiveness of EIA procedures, which is largely due to the difficulty of translating biodiversity assessments into clear management solutions. Biodiversity assessment and monitoring programs should consist of a list of protocols that apply reliable methods for recording living organisms in a spatial and temporal context. It is particularly noted that without "scientific rigor" and evaluation methodology the data collected cannot be relevant for decision-making and are a waste of time and money (Dias et al., 2017). The importance of the EIA procedure is emphasized, but it is noted that the findings of the procedure can be appealed as a result of methodological limitations, especially with respect to biodiversity impact assessment and conservation planning. It is shown that environmental niche modelling (Safaei et al., 2018; Rosas et al., 2019; Pecchi et al., 2019) can be a useful tool for planning biodiversity protection measures in the context of hydropower projects (Adhikari et al., 2019). However, approaches are not considered to take into account the multiscale ecological niche. As a proposal to improve the efficiency of the EIA procedure, the need to include the concept of ecosystem services is considered (Ochoa \& Urbina-Cardona, 2017), as it reflects the functioning of ecosystems and is a prerequisite for socio-economic well-being of people (Kuit et al., 2019; Sousa et al., 2020). Special emphasis is placed on the loss and fragmentation of settlements as a result of project implementation as the very cause of biodiversity decline. However, the scope and level of detail of biodiversity assessment that is not sufficient to make informed decisions is subject to criticism. Mismatches between the scale of environmental impacts and biodiversity assessments, imperfect assessments of anthropogenic impacts and impacts on common species are recognized to be key shortcomings (Bigard et al., 2017).

Animal community of soils is a reliable indicator of the direction of biogeocenotic processes (Gilarov, 1965). This situation is also true for artificial soil-like structures - technozems (Andrusevich et al., 2014; Zhukov et al., 2017, 2019). The design shortcomings of a technozem are clearly diagnosed by the peculiarities of the spatial organization of the soil macrofauna community. The procedure of RLQ-analysis makes it possible to estimate the interrelation of three most important characteristics of the soil ecosystem: edaphysical factors, species diversity and its ecomorphic structure (Dray \& Legendre, 2008; Seebacher et al., 2012; O. N. Kunah, 2016). Ecomorphs reflect features of adaptation of animals to different aspects 
of the biogeocenotic environment (Kunah, 2016; Maslikova, 2018; Zhukov, 2009; Zhukov et al., 2016). In the realities of a particular community, the associated variability of ecomorphs is observed, which opens up an opportunity to provide a dimensional description of its ecomorphic organization. The soil physical characteristics describe the ecological situation in the soil (Karpachevsky, 2005). Technozems as artificially created soil-like structures are characterized by high variability of properties (Yorkina et al., 2019; Zadorozhnaya et al., 2018; Zhukov \& Zadorozhnaya, 2016). The indicators should meet two requirements in order to characterize the spatial heterogeneity of the soil. First of all, it is ecological relevance, i.e., it is indicators that can informally reflect the features of soil as a habitat for plants and soil animals. Therefore, another criterion is important - to describe the spatial variability of ecological properties of the indicator must be relatively easy to measure, ie, in a short period of time can be obtained a significant amount of data (Gritsan et al., 2019; Kunah et al., 2018; Kunah \& Pap$\mathrm{ka}, 2016)$. Indicators such as soil penetration resistance, electrical conductivity and temperature can be measured in large quantities fairly quickly with the help of modern tools, and estimates of soil heterogeneities are clearly correlated with the properties of the soil animal community. Such an approach has shown its effectiveness in studying the soil macrofauna of forest biogeocenosis (Kunakh et al., 2020; Yorkina et al., 2019), forest urbanozem (Faly et al., 2017; N. V. Yorkina et al., 2019), the spatial distribution of the mole rats (Kolombar et al., 2014), and the role of the pedoturbation activity of mole rats in structuring the spatial organization of the community of herpetobiont spiders (Zhukov et al., 2011). The analysis of species marginality revealed that a visually homogeneous and relatively small area represents a heterogeneous habitat for soil animals. It was found that structural features of the technozem, which manifest themselves through the variability of hardness in the horizontal and vertical direction, lead to significant differentiation of the animal population of the soil of this area. The soil penetration resistance variability also affects the water regime of the soil, which affects the vegetation cover of the site, which is quantitatively reflected in the indicators of electrical conductivity and soil temperature, as well as the height of the grass (Smagin et al., 2011; Zhukov et al., 2019; Zhukov, Kunakh, et al., 2016).

Thus, an important aspect of standardizing EIA procedures in assessing anthropogenic impacts on biodiversity is the development of quantitative approaches to characterize ecosystem services. It was shown that ecosystem services are reflected in the ecomorphic structure of the soil animal community (Maslikova, 2018; Maslikova, 2018; Zhukov \& Maslikova, 2018; Zhukov et al., 2017; Zhukov et al., 2018). In this regard, our work is aimed at assessing the role of the ecomorphic structure of soil macrofauna community to indicate anthropogenic impacts.

\section{Material and methods}

The research was conducted on May 1, 2019 in the Botanical Garden of the Oles Gonchar Dnipro University. The investigated polygon № 14 is located on the gentle slope of the north-east exposition, which adjoins the spur of the Dolgaya beam $\left(48^{\circ} 25^{\prime} 52^{\prime \prime N}\right.$, $\left.35^{\circ} 2^{\prime} 17^{\prime \prime E}\right)$. The polygon is located between two walk-ways with asphalt pavement. The polygon consists of 15 transects perpendicular to the direction of Kozakov street. Each transect is composed of 7 test points. Distance between rows in the polygon is $2 \mathrm{~m}$. The site is an artificial forest park plantation, which grows in place of natural forest. Tree plants are represented by ashleaved maple (Acer negundo L.), false acacia (Robinia pseudoacacia L.), black mulberry (Morus nigra L.), shrubs are represented by black elderberry (Sambucus nigra L.). The celandine (Chelidonium majus L.), bedstraw (Galium aparine L.), herb bennet (Geum urbanum L.) have a high projection coverage in the herbaceous layer. The vegetation has a forest character $(96.23 \%$ of the projected coverage is represented by forest species). Phytoindication assessment allows the trophotope of the studied polygon to be assessed as mesotrophic $(90.57 \%$ of the projective coverage is mesotrophic). Hygrotope as a whole has mesophilic character $(83.02 \%$ of the projective coverage is represented by mesophiles).

Soil-zoological samples for the collection of soil macrofauna were taken at each point (the results are presented as L-table). The temperature, electrical conductivity, soil penetration resistance, litter thickness and the height of the grass were measured (presented as an R-table). The soil-zoological samples were $25 \times 25 \mathrm{~cm}$ in size. Soil penetration resistance was measured in the field using the Eijkelkamp handheld penetrometer to a depth of $50 \mathrm{~cm}$ at $5 \mathrm{~cm}$ intervals. The average error of the measurement results of the instrument is $\pm 8 \%$. Measurements were made with a cone with a crosssectional dimension of $2 \mathrm{~cm}^{2}$. Within each point of soil penetration resistance measurements were made in a single repeat. HI 76305 (Hanna Instruments, Woodsocket, R. I.) sensor was used for in situ measurements of soil conductivity. This sensor works in combination with a portable instrument HI 993310. The tester evaluates the total electrical conductivity of soil, i.e. the combined conductivity of soil air, water and particles. The measurement results of the device are presented in units of soil solution saturation with salts $-\mathrm{g} / \mathrm{l}$. Comparison of results of measurements with the device HI 76305 with the data of laboratory researches allowed to estimate the unit conversion coefficient as $1 \mathrm{dS} / \mathrm{m}=155 \mathrm{mg} / \mathrm{l}$ (Pennisi \& van Iersel, 2002). Soil temperature was measured in the period from 13 to 14 hours with digital thermometers WT-1 (PJSC "Steklopribor", http:// bit.steklopribor.com, accuracy $-0.1^{\circ} \mathrm{C}$ ) at a depth of 5-7 cm. The litter thickness was measured with a ruler, the height of the grass was measured with a measuring tape. Measurements of conductivity, temperature, height of the grass and litter thickness were made in three times at each test.

Ecological traits of species are linked with environmental conditions using RQL analysis (Dolédec et al., 1996). This analysis investigates the joint structure between three data tables: R-table (contains environment variables), Q-table (contains species traits) and L-table (abundance of species) (Dolédec et al., 1996; Dray et al., 2002). The L-table serves as a link between $R$ and $Q$ tables and measures the intensity of the link between them. Before the actual analysis, three separate analyses are performed. Correspondence analysis is used for the L-table, resulting in an optimal correlation structure between sites and species abundance weights. The ordination of R and Q tables is done by analyzing the principal components. Thus, RQL performs a coinertia analysis of $\mathrm{R}, \mathrm{Q}$ and $\mathrm{L}$ cross matrices. This analysis maximizes the covariance between the weights of the studied sites, taking into account the environmental properties expressed by Table R, and the weights of species, taking into account their environmental properties expressed by Table Q (Minden et al., 2012). The result is a better combined combination of the ordination of sites according to their environmental characteristics, the ordination of species according to their properties, and simultaneously the ordination of species and sites (Thuiller et al., 2004). The RQL-analysis combines three separate ordination solutions with maximization of covariance between species features and environmental properties through coineration analysis (Bernhardt-Römermann et al., 2008). Further, a hierarchical cluster analysis of species weights on two RQL axes using the Ward's method provides functional groups (Minden et al., 2012). The optimal number of groups can be obtained using the Calinski criterion (Caliñski \& Harabasz, 1974). Clusters show the distribution of species in space - ecological space (Doledec et al., 2000; Minden et al., 2012).

Soil animals are classified as different ecomorphs. Ecomorphs characterize the most common adaptations of animals to different aspects of the environment, as well as their role in ecosystem processes. In our work we consider soil animal ecomorphs such as cenomorphs, hygromorphs, cenotrophomorphs, topomorphs, phoromorphs, and trophomorphs. The term "morph" in the sense of ecomorphs is understood to mean the structure of an ecosystem, not anatomical features of an organism. The term "ecomorph" and 
some of its derivatives are often used in different meanings, but according to the principle of priority we use these terms in the meaning that was defined in the works of O. L. Belgard (Belgard, 1950, 1971). Ecomorphs are most often considered to be a feature of a given species; however, in the process of ontogenesis the ecomorphic features of species may change. Cenomorphs characterize the role of animals in the performance of the most representative for the territory types of cycling and energy flow: steppe, forest, grassland and wetlands. Accordingly, the following types are distinguished Cenomorphs as steppants (steppe species), silvants (forest species), pratants (grassland species), and palludants (wetland species). Hygromorphs refers to the preferences of organisms for living in certain humidity conditions. They include: xerophiles (preferring conditions of moisture deficit), mesophiles (preferring conditions of moderate humidification), hygrophiles (prefer conditions of high humidification), ultrahygrophiles (prefer conditions of over wetness and transition to aquatic habitat). Cenotrophomorphs are analogs of plant trophomorphs, which indicate a preference for a particular regime of soil nutrients for plants - trophicity, or fertility. The factor of trophicity does not influence directly on animals, but has an indirect cenotrophomorph effect through the peculiarities of the plant cover and related physical and chemical regimes of soil, so this ecomorph is called cenotrophomorph. Among cenotrophomorphs are distinguished such variants as oligotrophocenomorphs (prefer poor soils - not found in our study), mesotrophocenomorphs (prefer moderate soil fertility), megatrophocenomorphs (prefer soil rich in fertility level), ultramegatrophocenomorphs (prefer soils with extremely high mineralization level of soil solution, which are transitional to saline soils). Topomorphs characterize the preferences of animals to a certain soil layer and include endogeic are inhabitants of soil strata, epigeic are inhabitants of soil litter and upper soil layers, anecic live both in the soil and in the litter, moving in the soil through a system of tunnels that create themselves as earthworms, or use created by other species. Phoromorphs reflect the specifics of animal movement in the soil and the associated facilitation of the movement of other living organisms in the soil, as well as animal-induced specifics of substance transport in the soil. The term comes from the Latin phoresis or Greek $\varphi \rho \rho \varepsilon ́ \sigma \varepsilon l$, which means "carry". There are two main groups of the phoromorphs: animals moving by means of the existing soil cracks (A) and animals moving by means of the active soil borrowing and tunnels creating (B). Among the first group, there are animals whose body size is less than the soil cracks (A1), animal whose body size is commensurate with the soil cracks (A2), and animal whose body size is more than size of the cavities in the litter or commensurate with the large cracks or cavities in the soil (A3). Among the second group, there are animals moving with changing of the body thickness (B4), moving without changing of the body thickness (B5), digging holes in the soil with the help of the limbs (B6), and animals that have the C-shape of the body (B7). Trophomorphs are traditional trophic groups among which the most general, namely saprophages, phytophages, and zoophages are distinguished (Zhukov, 2009).

Characteristics of the ecomorphs of plants are given by Belgard $(1950,1971)$ and Tarasov (2012), $Q$-table is represented by ecomorphs of soil animals (Zhukov, 2009). The relationships between species traits and environmental properties are usually evaluated by statistical procedures of RLQ and OMI analyses using the ade4 package for the R Project for Statistical Computing (The R Foundation..., 2020). The RLQ value was evaluated using the randtest. rlq procedure.

\section{Results}

The characteristics of taxonomic and ecological diversity of the soil macrofauna community of the study site are presented in Table 1.

In the investigated area 35 species of soil animals were found. The density of soil macrofauna of the studied polygon was 1004.04 ind. $/ \mathrm{m}^{2}$. Oligohaeta were represented by enchitreids and earthworms. The earthworms were numerous and diverse group of saprophages within the polygon and were represented by 7 species. Earthworms accounted for $60.77 \%$ of the total population of the soil macrofauna. Aporrectodea trapezoides, the topsoil earthworm, was the dominant species. Its population was 262.10 ind. $/ \mathrm{m}^{2}$. The topsoil earthworms were also Aporrectodea rosea and Octolasion lacteum, litter dwelling were Dendrobaena octaedra, Dendrodrilus rubidus tenuis, and Eisenia fetida, soil and litter dwelling was Lumbricus rubellus. The earthworms hygromorphs were represented by ul-trahygrophiles, hygrophiles, and mesophiles. Among the earthworms prevail silvants, there are also pratants and steppants. Thus, the complex of earthworms in the study area is abundant and diverse both in taxonomic and ecological aspects.

In addition to earthworms, the trophic group of saprophages includes vegetable-eating millipeds Megaphyllum rossicum $\left(2.44\right.$ ind. $\left./ \mathrm{m}^{2}\right)$, flat-backed millipedes Schizothuranius dmitriewi (15.24 ind. $\left./ \mathrm{m}^{2}\right)$ and woodlice Trachelipus rathkii $\left(17.22\right.$ ind. $\left./ \mathrm{m}^{2}\right)$ and Cetonia aurata larvae $\left(0.15\right.$ ind.$\left./ \mathrm{m}^{2}\right)$. Predatory millipedes are represented by centipedes Geophilus proximus (30.63 ind. $\left.\mathrm{m}^{2}\right)$, and Lithobius forficatus (ind. $/ \mathrm{m}^{2}$ ) and scolopendra Cryptops anomalans $\left(0.15\right.$ ind.$\left./ \mathrm{m}^{2}\right)$. Predators are also represented by adults of beetles (Calathus fuscipes, Stomis pumicatus), larvae of the click beetles (Athous haemorrhoidalis and Melanotus brunnipes), larvae of the Diptera Stratiomyidae and herpetobiont spiders. The group of phytophages is diverse and represented by the larvae of gnawing scoop (Noctuidae), adults of beetle (Amara similata, Harpalus griseus, H. rufipes), molluscs ( 8 species). The dominant species of the molluscs is Discus ruderatus $\left(119.47\right.$ ind. $\left./ \mathrm{m}^{2}\right)$. The basis of the cenomorphic structure of the soil macrofauna of the polygon is formed by pratants $(51.4 \%$ in abundance), somewhat less silvants $(21.9 \%)$, step-pants $(14.0 \%)$ and palludants $(12.7 \%)$ (Fig. 1). Thus, the cenomorphic features of animals community of the study area can be characterized as forest and meadow.

Among hygromorphs, mesophiles prevailed (46.4\%), slightly less were hygromorphes $(25.1 \%)$, ultrahigrophiles $(22.8 \%)$ and xerophiles $(5.7 \%)$. Hygromorphic structure of the population was hygromesophilic. The community was dominated by mesotrophocenomorphs $(73.5 \%)$. The structure of topomorphs is dominated by endogeic forms $(56.0 \%)$. A very low representation of the anecic $(3.1 \%)$ was characteristic of the community. In the trophic structure, saprophages $(74.6 \%)$ were the absolute dominants. The proportion of zoophages was $4.2 \%$, and proportion of phytophages was $21.2 \%$. Among the phoromorphs dominated animals, which are able to actively create soil channels with changes in body shape (B4, 60.8\%). There were slightly fewer animals that use the existing cracks in the soil, the size of the body is larger than the cavities in the litter or commensurate with large gaps or cracks in the soil (A3, 21.1\%).

Edaphic characteristics can be considered as determinants of the ecological space of a soil macrofauna community (Table 2).

The soil penetration resistance in the studied area was characterized by the monotonic increase with depth. The soil penetration resistance in the upper soil layer was $1.47 \mathrm{MPa}$ on average and 4.11 $\mathrm{MPa}$ in the lower layer. Average values of the soil penetration resistance within the study area exceed critical for the growth of plant root systems (3-3.5 MPa) (Medvedev, 2009) already starting from $30-35 \mathrm{~cm}$ soil layers. However, minimum soil penetration resistance values of $0.5 \mathrm{MPa}$ were observed up to the maximum measured depth. It allows to assume a high structural influence of spatial variability of the soil penetration resistance on organization of soil animal community. The local maximum of coefficient of variation of the soil penetration resistance was observed in soil layers 35-40 $\mathrm{cm}$ and was $41.00 \%$. In soil layers from the depth 55-60 to 80-85 $\mathrm{cm}$ the coefficient of variation was almost at the identical level $(27.71-28.14 \%)$. At greater depths there was a sharp increase in the coefficient of variation to the level of 46.5-47.56\%, which was due to the occurrence in some places of the landfill construction waste at a depth of $85-100 \mathrm{~cm}$. 
Table 1. Species composition and abundance of soil macrofauna of site 14

\begin{tabular}{|c|c|c|c|c|c|c|c|c|c|}
\hline Class & Family & Species & $\begin{array}{l}\text { Ceno- } \\
\text { morph }\end{array}$ & $\begin{array}{l}\text { Hygro- } \\
\text { morph }\end{array}$ & $\begin{array}{l}\text { Ceno- } \\
\text { tropho- } \\
\text { morph }\end{array}$ & $\begin{array}{l}\text { Topo- } \\
\text { morph }\end{array}$ & $\begin{array}{c}\text { Tropho- } \\
\text { morph }\end{array}$ & $\begin{array}{l}\text { Phoro- } \\
\text { morph }\end{array}$ & $\begin{array}{c}\text { Abundance, } \\
\text { ind. } / \mathrm{m}^{2}\end{array}$ \\
\hline \multirow{8}{*}{ Oligohaeta } & Enchytraeidae & Enchytraeidae & $\operatorname{Pr}$ & $\mathrm{UHg}$ & $\mathrm{MsTr}$ & End & $\mathrm{SF}$ & A1 & 105.90 \\
\hline & \multirow{7}{*}{ Lumbricidae } & Aporrectodea caliginosa trapezoides (Duges, 1828) & $\operatorname{Pr}$ & Ms & $\mathrm{MsTr}$ & End & $\mathrm{SF}$ & B4 & 262.10 \\
\hline & & Aporrectodea rosea rosea (Savigny, 1826) & St & Ms & $\operatorname{Mg} \operatorname{Tr}$ & End & $\mathrm{SF}$ & B4 & 83.20 \\
\hline & & Dendrobaena octaedra (Savigny, 1826) & $\operatorname{Pr}$ & $\mathrm{UHg}$ & $\operatorname{MsTr}$ & Ep & $\mathrm{SF}$ & B4 & 80.61 \\
\hline & & Dendrodrilus rubidus tenuis (Eisen, 1874) & $\operatorname{Pr}$ & $\mathrm{Hg}$ & $\operatorname{MsTr}$ & Ep & $\mathrm{SF}$ & B4 & 0.91 \\
\hline & & Eisenia fetida (Savigny, 1826) & Sil & $\mathrm{UHg}$ & $\operatorname{MgTr}$ & Ep & SF & B4 & 2.13 \\
\hline & & Lumbricus rubellus Hoffmeister, 1843 & Sil & $\mathrm{Hg}$ & $\operatorname{MsTr}$ & Ep & $\mathrm{SF}$ & B4 & 71.01 \\
\hline & & Octolasion lacteum (Oerley, 1885) & Sil & Ms & $\mathrm{MsTr}$ & End & $\mathrm{SF}$ & B4 & 107.73 \\
\hline Arachnida & Aranei & Aranei & St & Ms & $\operatorname{MsTr}$ & Ep & $\mathrm{ZF}$ & A3 & 1.37 \\
\hline \multirow{3}{*}{ Chilopoda } & Cryptopidae & Cryptops anomalans Newport 1844 & St & Ks & $\operatorname{Mg} \operatorname{Tr}$ & End & $\mathrm{ZF}$ & $\mathrm{A} 2$ & 0.15 \\
\hline & Geophilidae & Geophilus proximus C.L.Koch 1847 & $\operatorname{Pr}$ & $\mathrm{Hg}$ & $\operatorname{MsTr}$ & Anec & $\mathrm{ZF}$ & A2 & 30.63 \\
\hline & Lithobiidae & Lithobius (Lithobius) forficatus (Linnaeus 1758) & Sil & Ms & $\operatorname{MsTr}$ & Ep & $\mathrm{ZF}$ & A3 & 0.15 \\
\hline \multirow{2}{*}{ Diplopoda } & Julidae & Megaphyllum rossicum (Timotheew, 1897) & $\operatorname{Pr}$ & Ms & $\operatorname{Mg} \operatorname{Tr}$ & Ep & SF & $\mathrm{A} 3$ & 2.44 \\
\hline & Polydesmidae & Schizothuranius dmitriewi (Timotheew, 1897) & $\operatorname{Pr}$ & $\mathrm{UHg}$ & $\operatorname{MsTr}$ & Ep & $\mathrm{SF}$ & A3 & 15.24 \\
\hline \multirow{12}{*}{ Insecta } & \multirow{6}{*}{ Carabidae } & Amara similata (Gyllenhal, 1810) & $\operatorname{Pr}$ & $\mathrm{Hg}$ & $\mathrm{MgTr}$ & Ep & $\mathrm{FF}$ & A1 & 0.30 \\
\hline & & Calathus (Calathus) fuscipes (Goeze, 1777) & St & Ks & $\mathrm{UMg} \operatorname{Tr}$ & Ep & $\mathrm{ZF}$ & A1 & 0.91 \\
\hline & & Carabidae (larv.) & St & Ms & $\operatorname{Olg} \operatorname{Tr}$ & Ep & $\mathrm{ZF}$ & $\mathrm{A} 3$ & 0.61 \\
\hline & & Harpalus (Pseudoophonus) griseus Panzer, 1796 & St & Ks & $\mathrm{UMgTr}$ & Ep & $\mathrm{FF}$ & A1 & 1.52 \\
\hline & & Harpalus (Pseudoophonus) rufipes (De Geer, 1774) & St & Ks & $\operatorname{Mg} \operatorname{Tr}$ & Ep & $\mathrm{FF}$ & A1 & 3.35 \\
\hline & & Stomis (Stomis) pumicatus (Panzer 1796) & Sil & Ms & $\operatorname{MgTr}$ & End & $\mathrm{ZF}$ & A1 & 0.30 \\
\hline & Cetoniidae & Cetonia aurata (Linnaeus 1761) & Pal & Ms & $\operatorname{MsTr}$ & End & SF & B7 & 0.15 \\
\hline & \multirow{2}{*}{ Elateridae } & Athous (Athous) haemorrhoidalis (Fabricius 1801) & $\operatorname{Pr}$ & $\mathrm{Hg}$ & $\operatorname{Mg} \operatorname{Tr}$ & End & $\mathrm{ZF}$ & B5 & 0.30 \\
\hline & & Melanotus (Melanotus) brunnipes (Germar 1824) & St & Ks & $\operatorname{MsTr}$ & End & $\mathrm{ZF}$ & B5 & 0.30 \\
\hline & Staphilinidae & Staphylinus caesareus Cederhjelm 1798 & Sil & Ms & $\mathrm{MsTr}$ & Ep & $\mathrm{ZF}$ & A1 & 2.29 \\
\hline & Stratiomyidae & Stratiomyidae & Sil & Ms & $\operatorname{MsTr}$ & Ep & $\mathrm{ZF}$ & A2 & 5.18 \\
\hline & Noctuidae & Noctuidae & Sil & Ks & $\operatorname{Ms} \operatorname{Tr}$ & End & $\mathrm{FF}$ & B4 & 1.83 \\
\hline Malacostraca & Trachelipodidae & Trachelipus rathkii (Brandt 1833) & $\operatorname{Pr}$ & $\mathrm{UHg}$ & $\operatorname{MsTr}$ & Ep & $\mathrm{SF}$ & $\mathrm{A} 3$ & 17.22 \\
\hline \multirow{8}{*}{ Gastropoda } & Enidae & Brephulopsis cylindrica (Menke, 1828) & St & $\mathrm{Ks}$ & $\operatorname{MgTr}$ & Ep & $\mathrm{FF}$ & A3 & 1.52 \\
\hline & Cochlicopidae & Cochlicopa lubrica (Müller 1774) & Sil & $\mathrm{Hg}$ & $\mathrm{MsTr}$ & Ep & $\mathrm{FF}$ & A1 & 29.10 \\
\hline & Endodontidae & Discus ruderatus (Hartmann, 1821) & Pal & $\mathrm{Hg}$ & $\mathrm{UMg} \operatorname{Tr}$ & Ep & $\mathrm{FF}$ & A3 & 119.47 \\
\hline & Enidae & Chondrula tridens (O.F. Muller 1774) & St & Ks & $\mathrm{UMgTr}$ & Ep & $\mathrm{FF}$ & A3 & 48.00 \\
\hline & Limacidae & Limax sp. & Sil & $\mathrm{Hg}$ & $\mathrm{Olg} \operatorname{Tr}$ & Ep & $\mathrm{FF}$ & B4 & 0.46 \\
\hline & Succineidae & Succinea oblonga (Draparnaud 1801) & Pal & $\mathrm{UHg}$ & $\operatorname{MsTr}$ & Ep & $\mathrm{FF}$ & $\mathrm{A} 3$ & 1.22 \\
\hline & Valloniidae & Vallonia pulchella (Müller, 1774) & Pal & $\mathrm{UHg}$ & $\mathrm{UMgTr}$ & Ep & $\mathrm{FF}$ & A1 & 1.83 \\
\hline & Vitrinidae & Vitrina pellucida (Müller, 1774) & Pal & $\mathrm{UHg}$ & $\mathrm{MsTr}$ & Ep & $\mathrm{FF}$ & A3 & 4.57 \\
\hline
\end{tabular}

Symbols. Cenomorphs: St - steppants, Pr - pratants, Pal - palludants, Sil - sil-vants; Hygromorphs: Ks - xerophiles, Ms - mesophiles, $\mathrm{Hg}$ - hygrophiles, UHg - ultrahygrophiles; Cenotrophomorphs: MsTr - mesotrophocenomorphs; MgTr - megatrophocenomorphs; $\mathrm{UMgTr}$ - ultramegatrophocenomorphs; Topo-morphs: End - endogeic, Ep - epigeic, Anec - anecic; Phoromorphs: A - moving by means of the existing soil cracks; B - moving by means of the active soil bor-rowing and tunnels creating (A1 - the animal body size is less than the soil cracks; A2 - the animal body size is commensurate with the soil cracks; A3 - the animal body size is more than size of the cavities in the litter or commensurate with the large cracks or cavities in the soil; B4 - moving with changing of the body thickness; B5 - moving without changing of the body thickness; B6 - dig-ging holes in the soil with the help of the limbs; B7 - C-shape of the body); Trophomorphs: $\mathrm{SF}$ - saprophages; FF - phytophages; ZF - zoophages.

The electrical conductivity of the soil was $0.48 \mathrm{dSm} / \mathrm{cm}$ on average and was characterized by a coefficient of variation of $32.20 \%$. Maximum values reached the level of $0.88 \mathrm{dSm} / \mathrm{m}$, which was much lower than the lower threshold of negative impact on vegetation of a high concentrations of the electrolyte $-1.5-2.0 \mathrm{dSm} / \mathrm{m}$ (Smagin et al., 2006, 2018). The temperature of the soil layer 5-7 cm during the study period was $16.32^{\circ} \mathrm{C}$ with a coefficient of variation of $7.83 \%$. The thickness of plant litter within the site was at the level of 0.96 $\mathrm{cm}$ with coefficient of variation of $61.70 \%$. Coefficient of variation for grass height was $32.02 \%$ with the average level of this index being $45.78 \mathrm{~cm}$.
The combined measurement of soil characteristics and features of the animal community structure allowed to estimate the properties of the ecological niche of the soil macrofauna (Table 3).

The total inertia that can be calculated from the OMI analysis is proportional to the average marginality of community species and is a quantitative assessment of the influence of environmental factors on species separation. The OMI analysis found that the total inertia was 0.43 . The first axis from the OMI analysis described $63.53 \%$ and the second axis $19.18 \%$ of inertia. Thus, the first two axes described $82.71 \%$ of inertia, which was quite enough to describe the differentiation of ecological niches of macrofauna in the stu- 


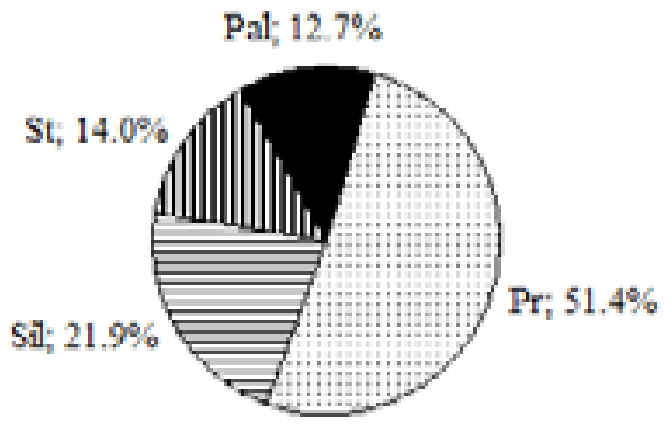

Cenomorphs

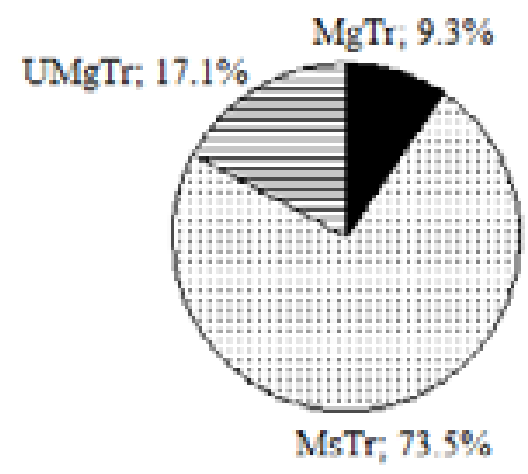

Cenotrophomorphs

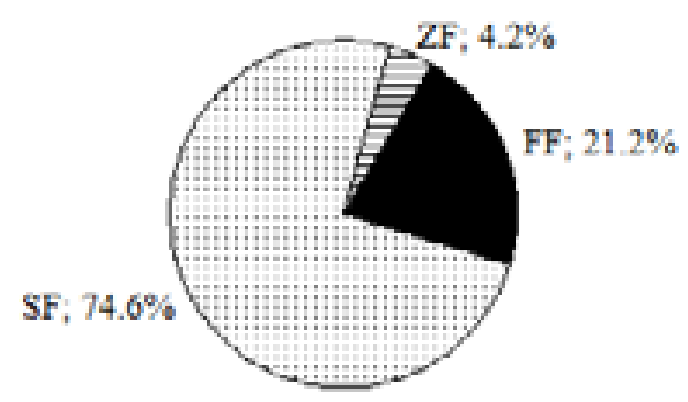

Trophomorphs

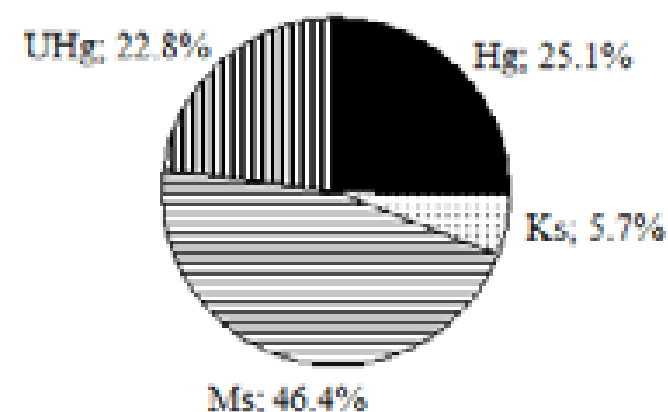

Hygromorphs

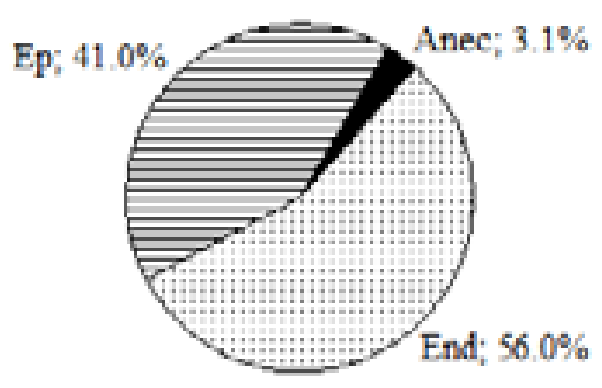

Topomorphs

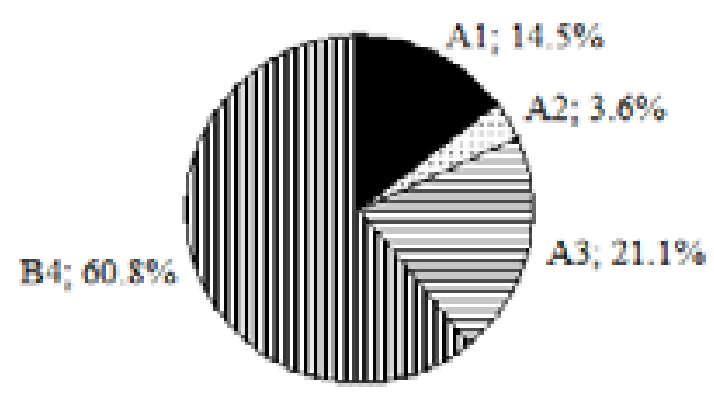

Phoromorphs

Fig. 1. The ecological structure of the soil macrofauna:

Cenomorphs: St - steppants, Pr - pratants, Pal - palludants, Sil - silvants; Hygromorphs: Ks - xerophiles, Ms - mesophiles, $\mathrm{Hg}$ - hygrophiles, UHg - ultrahygrophiles; Cenotrophomorphs: MsTr - mesotrophocenomorphs; $\operatorname{Mg} \operatorname{Tr}$ - megatrophoceno-morphs; $\mathrm{UMgTr}$ - ultramegatrophocenomorphs; Topomorphs: End - endogeic, Ep - epigeic, Anec - anecic; Phoromorphs: A - moving by means of the existing soil cracks; B - moving by means of the active soil borrowing and tunnels creating (A1 - the animal body size is less than the soil cracks; A2 - the animal body size is commensurate with the soil cracks; A3 - the animal body size is more than size of the cavities in the litter or commensurate with the large cracks or cavities in the soil; B4 - moving with changing of the body thickness; B5 - moving without changing of the body thickness; B6 - digging holes in the soil with the help of the limbs; B7 - C-shape of the body); Trophomorphs: $\mathrm{SF}$ - saprophages; FF - phytophages; ZF - zoophages 
O. M. Kunakh, N. V. Yorkina, Y. O. Zhukova, A. S. Malasay

Environmental impact assessment: possible application of the ecomorphic approach

Table 2. Determinants of the ecological space of the soil macrofauna

\begin{tabular}{|c|c|c|c|c|c|c|}
\hline \multirow{2}{*}{ Environment parameter } & \multirow{2}{*}{ Mean } & \multicolumn{2}{|c|}{ Confidence interval } & \multirow{2}{*}{$\mathrm{CV}, \%$} & \multirow{2}{*}{ RLQ axes 1} & \multirow{2}{*}{ RLQ axes 2} \\
\hline & & $-95 \%$ & $+95 \%$ & & & \\
\hline \multicolumn{7}{|c|}{ Soil penetration resistance at the depth, $M P a$} \\
\hline $0-5 \mathrm{~cm}$ & 1.47 & 1.42 & 1.52 & 18.71 & 0.22 & 0.24 \\
\hline $5-10 \mathrm{~cm}$ & 1.94 & 1.86 & 2.02 & 21.20 & -0.16 & -0.27 \\
\hline $10-15 \mathrm{~cm}$ & 2.38 & 2.24 & 2.52 & 30.10 & -0.61 & -0.33 \\
\hline $15-20 \mathrm{~cm}$ & 2.77 & 2.56 & 2.98 & 39.01 & -0.71 & -0.42 \\
\hline $20-25 \mathrm{~cm}$ & 2.99 & 2.76 & 3.23 & 40.34 & -0.77 & -0.46 \\
\hline $25-30 \mathrm{~cm}$ & 3.11 & 2.85 & 3.36 & 42.14 & -0.86 & -0.48 \\
\hline $30-35 \mathrm{~cm}$ & 3.20 & 2.94 & 3.45 & 41.00 & -0.89 & -0.46 \\
\hline $35-40 \mathrm{~cm}$ & 3.32 & 3.08 & 3.56 & 37.51 & -0.92 & -0.42 \\
\hline $40-45 \mathrm{~cm}$ & 3.49 & 3.26 & 3.72 & 34.08 & -0.92 & -0.35 \\
\hline $45-50 \mathrm{~cm}$ & 3.59 & 3.37 & 3.82 & 31.86 & -0.92 & -0.28 \\
\hline $50-55 \mathrm{~cm}$ & 3.76 & 3.55 & 3.96 & 27.71 & -0.94 & -0.29 \\
\hline $55-60 \mathrm{~cm}$ & 3.85 & 3.65 & 4.05 & 27.05 & -0.94 & -0.27 \\
\hline $60-65 \mathrm{~cm}$ & 3.85 & 3.65 & 4.06 & 27.80 & -0.92 & -0.21 \\
\hline $65-70 \mathrm{~cm}$ & 3.92 & 3.71 & 4.13 & 27.68 & -0.91 & -0.28 \\
\hline $70-75 \mathrm{~cm}$ & 3.93 & 3.72 & 4.15 & 28.23 & -0.88 & -0.32 \\
\hline $75-80 \mathrm{~cm}$ & 3.95 & 3.73 & 4.16 & 28.14 & -0.87 & -0.30 \\
\hline $80-85 \mathrm{~cm}$ & 4.10 & 3.73 & 4.47 & 46.50 & -0.88 & -0.19 \\
\hline $85-90 \mathrm{~cm}$ & 4.08 & 3.71 & 4.45 & 47.00 & -0.84 & -0.12 \\
\hline $90-95$ см & 4.07 & 3.69 & 4.44 & 47.56 & -0.80 & -0.09 \\
\hline $95-100 \mathrm{~cm}$ & 4.11 & 3.74 & 4.48 & 46.50 & -0.79 & -0.09 \\
\hline \multicolumn{7}{|c|}{ Physical properties, litter thickness and grass height } \\
\hline Electrical conductivity, $\mathrm{dSm} / \mathrm{cm}$ & 0.48 & 0.45 & 0.50 & 32.20 & -0.54 & -0.53 \\
\hline $\begin{array}{l}\text { Soil temperature at } 5-7 \mathrm{~cm},{ }^{\circ} \mathrm{C} \text {, } \\
04.05 .2019\end{array}$ & 16.32 & 16.07 & 16.57 & 7.83 & -0.68 & -0.39 \\
\hline 31.08 .2019 & 17.95 & 17.82 & 18.09 & 3.88 & 0.56 & 0.25 \\
\hline Litter thickness, $\mathrm{cm}$ & 0.96 & 0.84 & 1.07 & 61.70 & -0.06 & 0.67 \\
\hline Grass height, $\mathrm{cm}$ & 45.78 & 42.95 & 48.62 & 32.02 & 0.05 & -0.29 \\
\hline
\end{tabular}

Table 3. Analysis of the marginality of macrofauna community species

\begin{tabular}{|c|c|c|c|c|c|c|}
\hline Species & Abreviation & Inertia & OMI & Tolerance & Rtol & p-level \\
\hline Aporrectodea trapezoides & A_trapezoides & 23.49 & 0.20 & 18.80 & 81.00 & 0.50 \\
\hline Aporrectodea rosea & A_rosea & 23.86 & 1.50 & 21.50 & 77.00 & 0.15 \\
\hline Aranei & Aranei & 15.21 & 21.40 & 22.90 & 55.70 & 0.15 \\
\hline Brephulopsis cylindrica & B_cylindrica & 24.08 & 42.90 & 21.90 & 35.20 & 0.05 \\
\hline Calathus fuscipes & C_fuscipes & 41.90 & 61.60 & 24.30 & 14.10 & 0.01 \\
\hline Chondrula tridens & Ch_tridens & 21.20 & 4.50 & 42.90 & 52.60 & 0.01 \\
\hline Cochlicopa lubrica & C_lubrica & 20.45 & 8.50 & 42.90 & 48.60 & 0.01 \\
\hline Dendrobaena octaedra & D_octaedra & 23.05 & 0.60 & 24.00 & 75.40 & 0.53 \\
\hline Discus ruderatus & D_ruderatus & 21.59 & 2.40 & 31.60 & 66.00 & 0.07 \\
\hline Eisenia fetida & E_fetida & 26.57 & 16.60 & 4.30 & 79.10 & 0.74 \\
\hline Enchytraeidae sp. & Enchytaeidae & 20.64 & 1.30 & 4.80 & 93.80 & 0.59 \\
\hline Geophilus proximus & G_proximus & 22.31 & 1.20 & 43.70 & 55.10 & 0.13 \\
\hline Harpalus griseus & $\mathrm{H} \_$griseus & 19.27 & 3.30 & 3.90 & 92.80 & 0.97 \\
\hline Harpalus rufipes & H_rufipes & 26.67 & 5.80 & 25.80 & 68.40 & 0.24 \\
\hline Megaphyllum rossicum & M_rossicum & 29.47 & 8.90 & 27.20 & 63.90 & 0.14 \\
\hline Lepidoptera sp. & Lepidoptera & 20.83 & 23.20 & 32.50 & 44.30 & 0.05 \\
\hline Lumbricus rubellus & L_rubellus & 24.69 & 0.10 & 3.10 & 96.80 & 0.93 \\
\hline Octolasion lacteum & O_lacteum & 22.51 & 0.40 & 22.10 & 77.40 & 0.28 \\
\hline Schizothuranius dmitriewi & Sch_dmitriewi & 23.63 & 2.40 & 25.70 & 71.80 & 0.16 \\
\hline Staphilinus caesareus & S_caesareus & 27.68 & 4.00 & 11.30 & 84.70 & 0.35 \\
\hline Stratiomyidae sp. & Stratiomyidae & 27.57 & 24.10 & 29.60 & 46.20 & 0.03 \\
\hline Succinea oblonga & S_oblonga & 19.57 & 21.30 & 31.30 & 47.30 & 0.05 \\
\hline Trachelipus rathkii & T_rathkei & 24.01 & 1.80 & 9.90 & 88.30 & 0.36 \\
\hline Vallonia pulchella & V_pulchella & 31.04 & 18.30 & 30.20 & 51.50 & 0.05 \\
\hline Vitrinia pellusida & $\mathrm{V} \_$pellucida & 23.34 & 12.40 & 31.90 & 55.70 & 0.01 \\
\hline OMI for community & & - & 3.18 & - & - & 0.01 \\
\hline
\end{tabular}

Symbols: OMI - outlying mean indexes (marginality) for each species; Tol - tolerance, Rtol - residual tolerance; presented index data in \% of total variability; p-level by Monte Carlo method after 999 iterations. 
died area. For the average value of community marginality $(\mathrm{OMI}=$ 3.18 ) the level of significance was $p=0.01$, which indicates the importance of the selected environment variables for structuring soil macrofauna community. Marginality, which statistically significantly differs from the random alternative, was typical for 10 species out of 25 for which OMI analysis was conducted (Table 3). Thus, for 10 macrofauna species of the study area typical soil conditions did not coincide with the centroid of their ecological niche. On the other hand, for the majority of species, the marginality did not reliably differ from the typical conditions within the polygon, which indicates that environmental conditions were optimal.

The marginality of the niche indicates the degree of difference between optimal conditions for the species from the typical conditions within this habitat. Niche tolerance is a value inverse of specialization: the greater the tolerance, the less specialization. Residual tolerance indicates the role of random, neutral factors and measurement errors. Such species as Calathus fuscipes, Brephulopsis cylindrica, Stratiomyidae were characterized by a high marginality. The typical ecological conditions presented within the studied habitat were significantly different from the optimal conditions for these species. However, the Megaphyllum rossicum and Brephulopsis cylindrica were characterized by a high tolerance. Low tolerance, and therefore high specialization, was typical for Lumbricus rubellus, Harpalus griseus and Eisenia fetida. Residual tolerance was quite high for these same species, which allows us to assume a significant role in the structuring of soil macrofauna community by neutral factors or other factors not considered in this study. Configuration of ecological niches of macrofauna is shown in Figure 2. The analysis of the data presented in Figure 2 shows that the key aspect of structuring the ecological niche of soil animals within the study area was the soil penetration resistance in layers $15-20, \ldots$. , 95-100 cm, litter thickness and electrical conductivity of soil (axis 1). The soil penetration resistance at the depth of $0-5-5-10 \mathrm{~cm}$, height of vegetation and temperature (axis 2) also played an important role.

The results of the RLQ analysis are presented in Table 2 and Figure 3. It was found that $97.28 \%$ of the total variation (total inertia) described the first two RLQ axes (89.95 and $7.33 \%$ respectively). The randtest procedure confirmed the significance of the RLQ analysis results at p-level 0.001 . RLQ axes are integral estimates of the relationship between environmental factors (in our case - soil characteristics, litter thickness and grass height), community structure and its ecomorphic organization. In one metric space we have an opportunity to display community structure (location of macrofauna species), sampling points (spatial component taking into account that coordinates of sampling points were fixed), weight of environmental factors and weight of ecomorphic characteristics of soil animals (Fig. 3). Axes 1 and 2, extracted as a result of RLQ analysis, characterize a significant role of the soil penetration resistance in structuring the soil macrofauna community at all measured

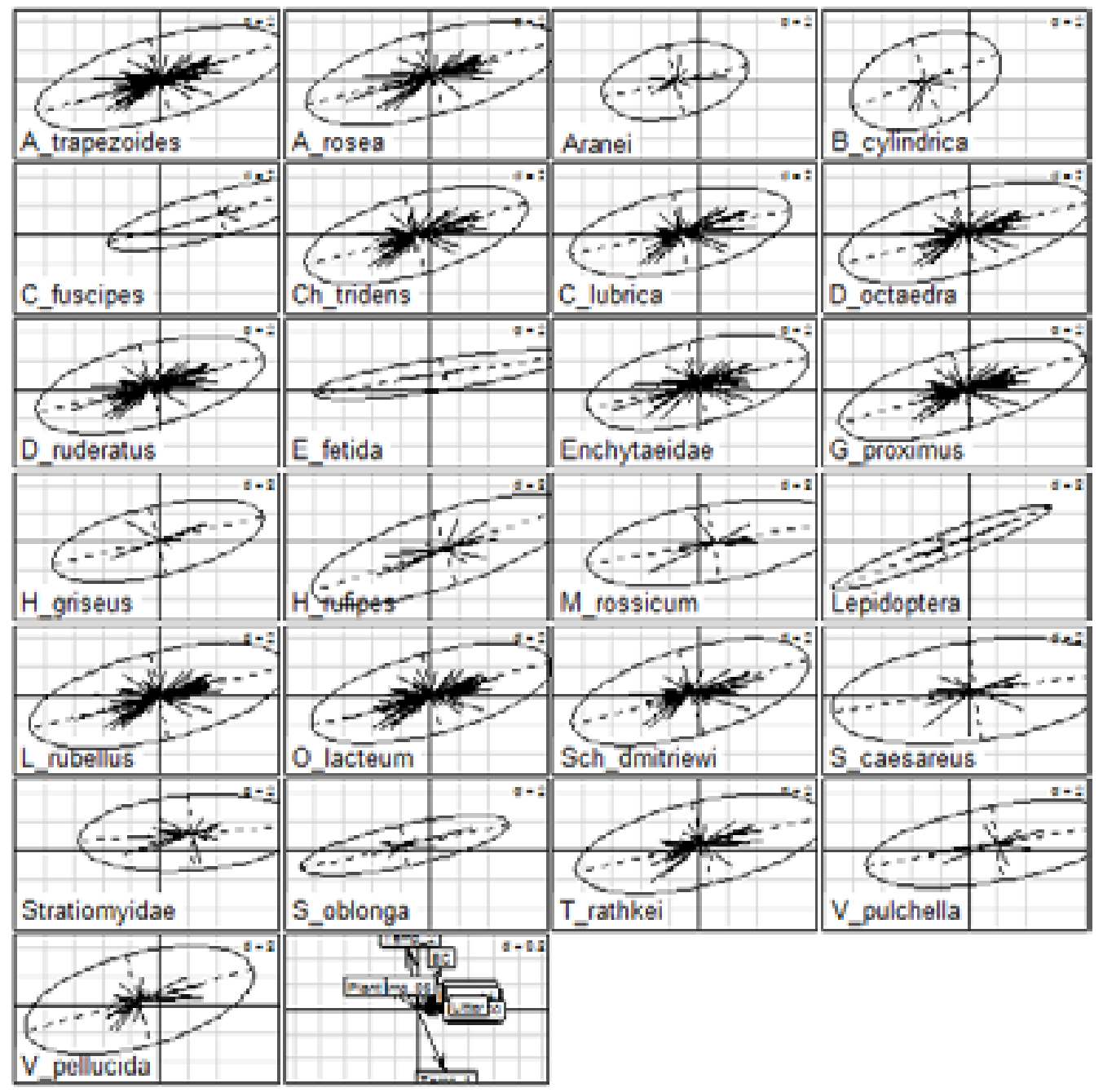

Fig. 2. Ecological niches of soil macrofauna species: Coordinate axes are given by components of marginality; the origin of coordinates is zero marginality. The ellipse indicates the inertia of the ecological niche. The rays connect the ecological niche centroid with the sites of species meeting in the community marginality space. In the lower right corner - normalized weights of ecological variables; abbreviated names of species - see Table 3 


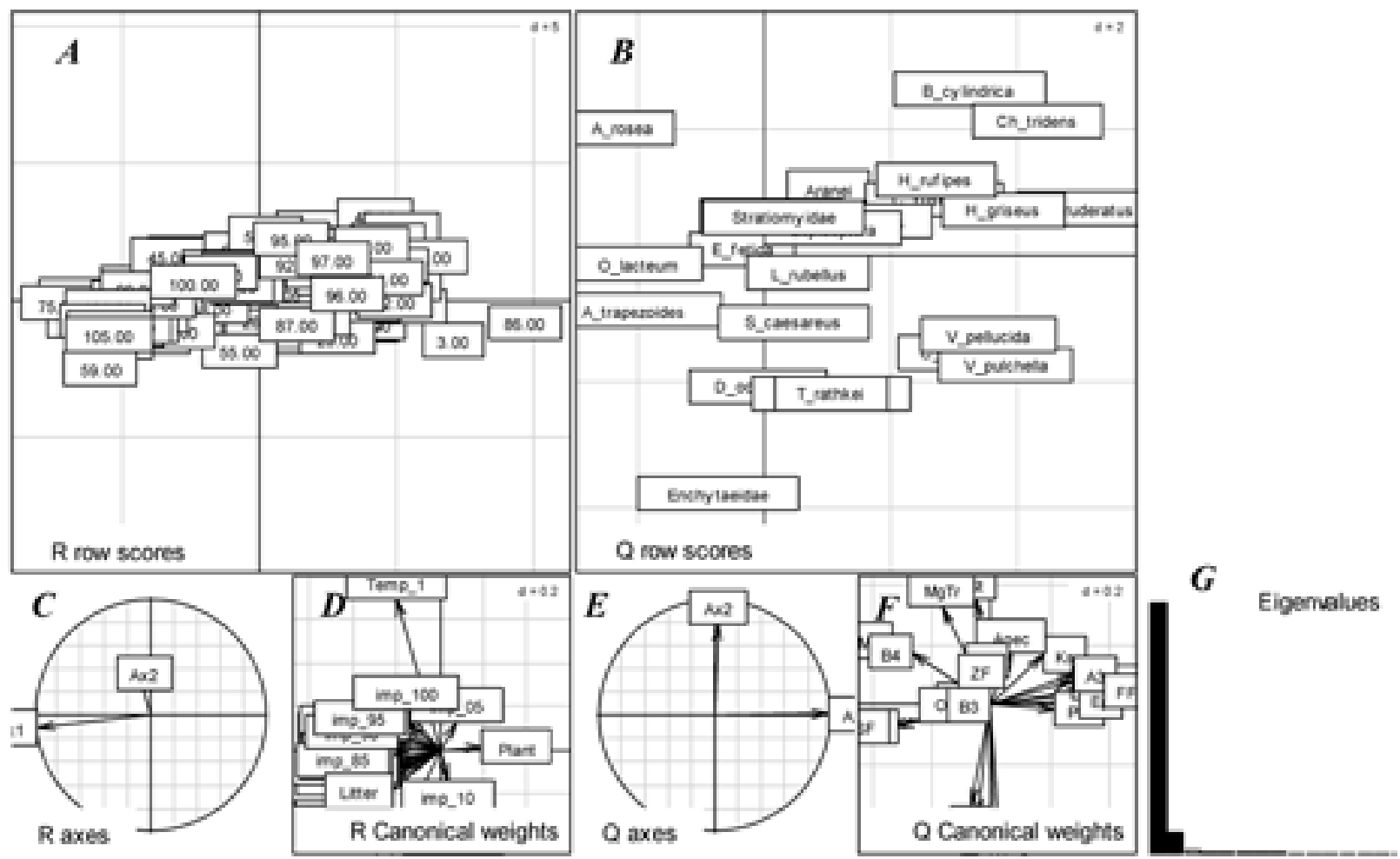

Fig. 3. RLQ analysis results: abscissa axis - RLQ-axis 1, ordinate axis - RLQ-axis 2; A - weights of sampling points (R-matrix) on RLQ axes; B - weights of species (Q-matrix) on RLQ axes; C - correlation of the principal components 1 and 2 obtained on the basis of factor analysis of environment variables and RLQ-axes; D - correlation of environment variables and RLQ-axes;

$\mathrm{E}$ - correlation of the principal components 1 and 2, obtained on the basis of factor analysis of ecomorphs and RLQ-axes;

$\mathrm{F}$ - correlation of ecomorphs and RLQ-axes; G - histogram of eigenvalues

depths (Table 1). The maximum structuring influence in the Axis 1 occurred at the depth of 40-45-70-75 cm. For Axis 2 such local maximums were 2 at a depth of $25-30-40-45 \mathrm{~cm}$ and $75-80$ and $80-85 \mathrm{~cm}$. Axis 1 indicates a unidirectional trend of soil penetration resistance variability and electrical conductivity, which leads to a decrease in the height of the grass. The height and obviously the projective coverage of the grass, negatively correlate with the litter thickness. This feature is probably the reason why Axis 1 is not related to the soil temperature. Axis 2 also has a similar relationship to soil penetration resistance, electrical conductivity, grass height and litter power, but this axis also reflects the variability in soil temperature. RLQ-analysis allows to classify animals according to the nature of their ecological structure and connection with environmental factors. Cluster analysis made it possible to identify 5 complexes of species that form functional groups A, B, C, D, E (Fig. 4).

The location of these functional groups in the RLQ space of the axes is shown in Figure 5. The centroid of functional group A occupies the area corresponding to negative values of RLQ of axis 1. As noted earlier, such values of axis 2 mark the increased penetration resistance and electrical conductivity of the soil, as well as the litter thickness. Functional group A combines exclusively earthworms. The combination of factors that determine the RLQ values of axis 1 can be interpreted as a result of terrain microlosses in which the litter accumulates and which have increased hydration due to moisture redistribution, resulting in increased electrical conductivity of the

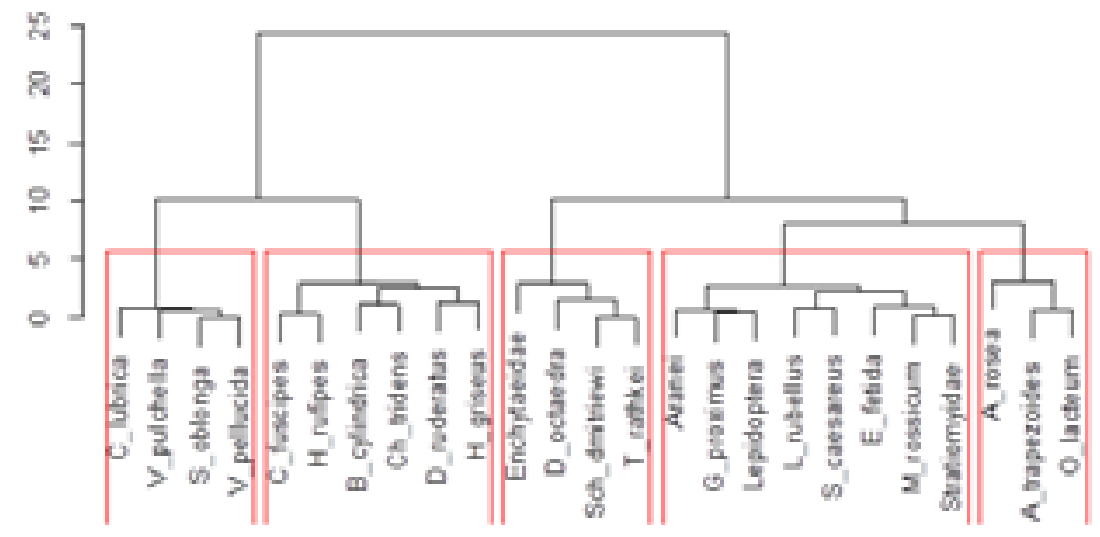

Fig. 4. Cluster analysis of the soil macrofauna community structure. A, B, C, D, E- functional groups 


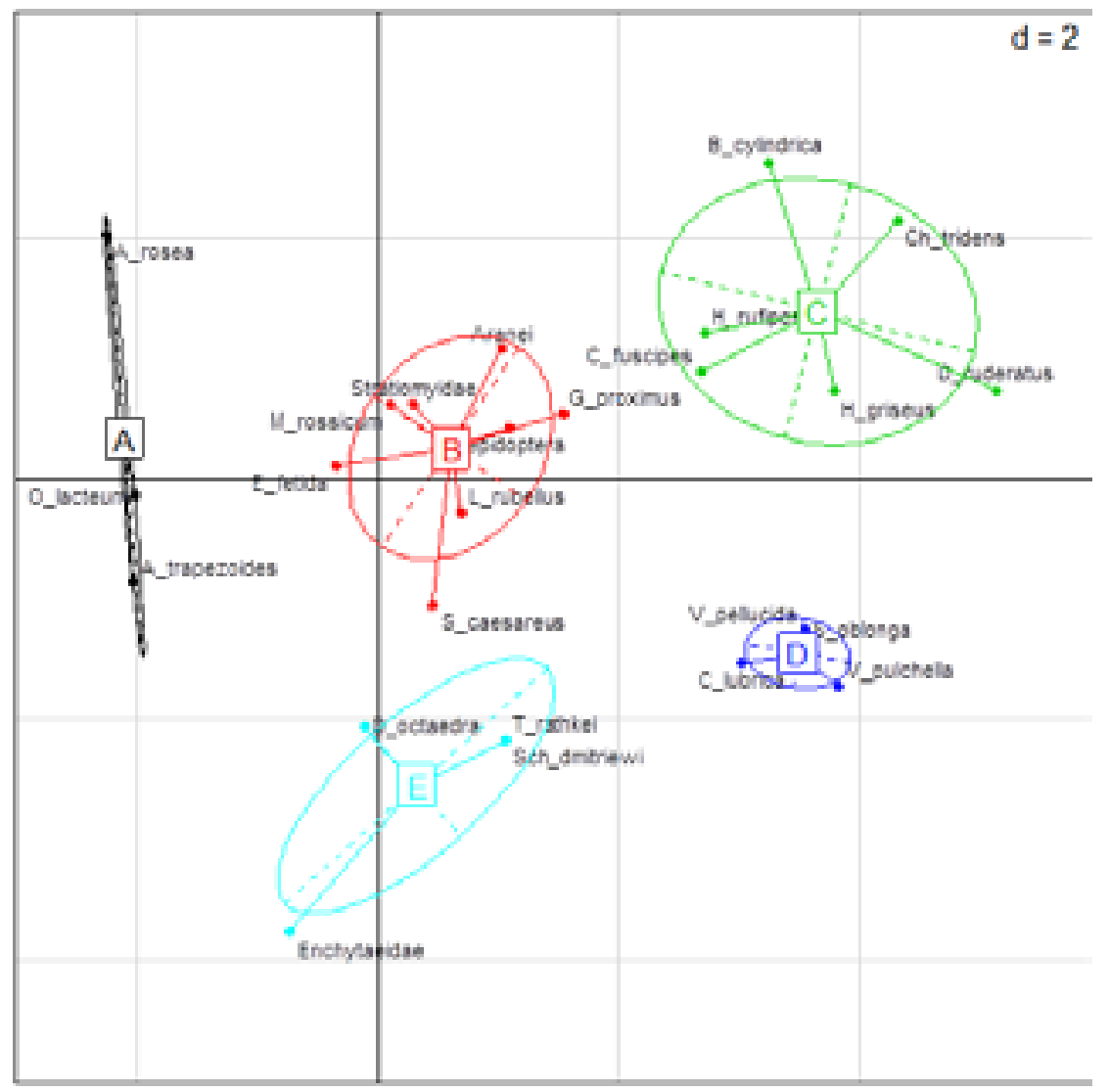

Fig. 5. Position of functional groups in RLQ-axis space. A, B, C, D, E - functional groups

soil. Obviously, localites corresponding to microlocations are characterized by increased soil penetration resistance. In ecological terms, functional group A can be characterized as endogenous saprophages.

The centroid of functional group B is closest to the beginning of coordinates, which indicates that its members occupy the most typical areas within the polygon. The markers of this functional group are silvants. It should be noted that according to the results of the general ecomorphic analysis, silvants occupy only the second place in the structure of the animal community after prattants. However, the ecomorphic analysis of vegetation shows that we have a forest monocoenosis. The RLQ analysis showed that despite its subordinate position in the soil macrofauna community, silvants occupy the most typical microstations for the polygon. This makes it possible to find correspondence between the results of the ecomorphic analysis carried out for the vegetation and animal community of the soil. The centroids of functional groups $\mathrm{C}$ and $\mathrm{D}$ occupy an extreme right-hand position on the axis, which indicates that they are confined to microsites with low soil penetration resistance and electrical conductivity and low litter thickness. The markers of these groups are epigeic phytophages. Functional group $\mathrm{C}$ has a more xerophilic form, tending to the steppe cenomorphs. Functional group D, on the contrary, is more hygrophilic and attracts to palludants. Axis 2 determines the antagonism between prattantultragygrophiles on the one hand and xerophylous on the other. The area of ultra-hydrophilic prattants is occupied by functional group $\mathrm{E}$, while the reverse position in the community is vacant.

The spatial position of RLQ-axis values is shown in Figure 6. The RLQ-1 axis is characterized by a significant linear trend $\left(R^{2}=0.59\right.$ for a linear regression model with coordinates as predic-
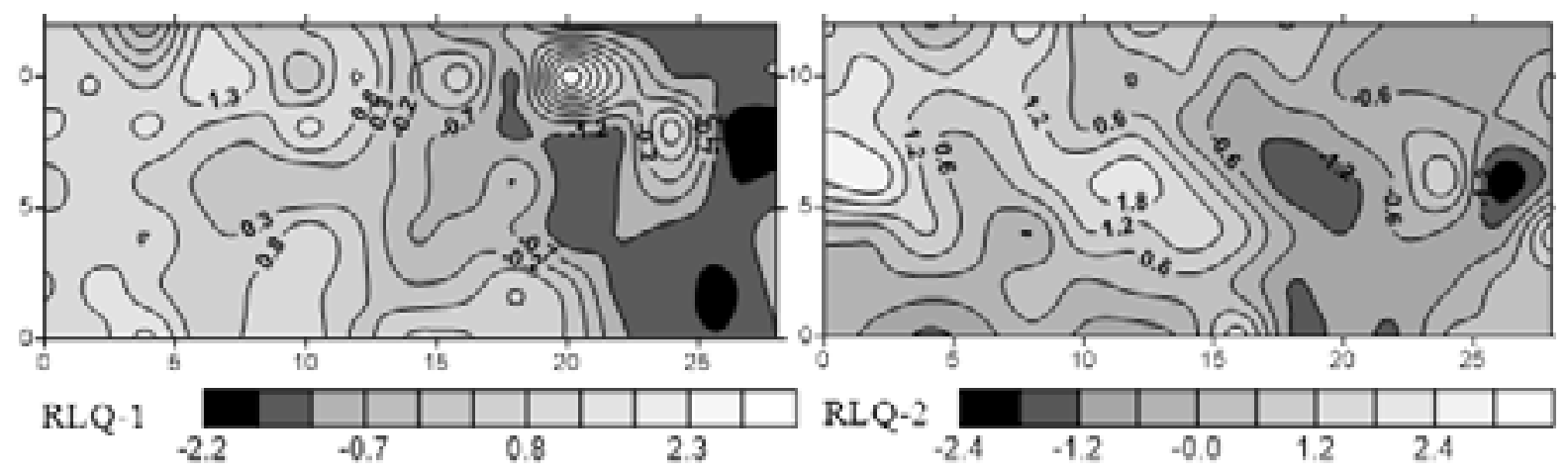

Fig. 6. Spatial variability of RLQ axes. The abscissa and ordinate axes are local coordinates, $\mathrm{m}$ 
tors). In the figure, the right side is bordered by an asphalted pedestrian walkway, behind which is the carriageway of Kozakov street. Water flowing down from the asphalt surface during precipitation or condensation may be the cause of increased soil moisture and electrical conductivity near the pedestrian walkway. Also, the junction between the open surface of the soil and the footpath is a place of accumulation of litter. Thus, the RLQ-1 axis should be considered as an indicator of anthropogenic transformation of the animal population in the soil. It should be noted that this axis essentially prevails over the next axis in its value which testifies to essential transformation of soil macrofauna community. The established RLQ axes also have an ecomorphic meaning that allows explaining the difference between the cenomorphic structure of vegetation and animal population. Animal population is more sensitive to anthropogenic transformation, which is manifested in a significant reorganization of the ecomorphic structure.

The role of the linear trend in the variability of the RLQ- 2 axis is considerably smaller $(\mathrm{R} 2=0.33)$. Axis 2 divides the studied polygon into two clearly separated sections - an ecotonic one, close to a footpath (its length to the right extends to the depth of 12-13 m) and located at the depth of an artificial forest array. Distinctive feature of the 2-axis from the 1-axis is closer connection with the height of the grass and the height of the bedding. The specific distribution in space of these ecological characteristics determines the spatial pattern of the RLQ-axis 2.

\section{Dicussion}

Ecomorphic structure characterizes different aspects of interrelation between soil animal community and environment, and also indicates the role that animals play in the soil formation process. Taxonomic diversity of a community is the basis of ecological diversity, which, in its turn, determines the stability and functional properties of the ecosystem as a whole (Gardiner et al., 2013; Moura \& Franzener, 2017; Zhukov et al., 2019). Anthropogenic impacts affect the ecological structure of a community (Marcotullio et al., 2008; Myers \& Patz, 2009; Mustafa et al., 2017). Different components of a community have different sensitivity to anthropogenic impacts. Anthropogenic impacts have a hierarchical structure, which in turn causes effects of different spatial or temporal dimensions in ecosystems (Roa-Fuentes \& Casatti, 2017). Our results indicate that the final ecomorphic structure of a soil macrofauna community is a superposition of structural components of different ecomorphic nature. The structural components divide the ecological space, which is the basis for community stability. The differentiation of ecological niches is one of such mechanisms (Horsák, 2006; Bartelheimer \& Poschlod, 2014; Zhukov et al., 2019; Larsen et al., 2020). On the other hand, functional groups are complexes of species that are characterized by a set of similar ecological requirements, which indicates a higher level of overlap of ecological niches and a higher level of competitive exclusion. It can be assumed that living in soil, along with competitive relations, implies the development of cooperative relations. Thus, the joint use of a system of soil tunnels can serve as one of the mechanisms for mutually beneficial cooperation. This hypothesis is confirmed by important role of soil penetration stability indicators as important marker of ecological space of soil macrofauna.

Anthropogenic impacts significantly alter the course of natural environmental processes and induce adequate changes in community structure. These changes can be identified and interpreted using the ecomorphic approach. Our results show that the anthropogenic factor, namely the recreational load, causes changes in the spatial organization of the humidity regime. The animal community reacts to this impact in a complex way by changing several aspects of the ecomorphic structure. It is important to note that the established patterns have their manifestation on a detailed level of community organization and are subject to mapping. Undoubtedly, such sensitivity of the ecomorphic approach makes it an effective tool for assessment of anthropogenic impact on habitats. The detecting of sustainable spatial patterns is also a way to confirm the anthropogenic nature of targeted changes in the structure of a soil macrofauna community and can be used to quantify it.

\section{Conclusions}

The results obtained indicate that the ecomorphic characteristics of the soil macrofauna community are informative high-value markers of the ecosystem state. The soil macrofauna community is differentiated into functional groups, which should be considered as a mechanism for maintaining stability of the community as a whole. Such structuring takes place both in the ecological and geographical space. The comparison of community projections in both these spaces makes it possible to interpret the selected functional groups in a meaningful way. It is important to note that both natural and anthropogenic factors have a structuring effect on the soil macrofauna community. An important aspect of anthropogenic impact is the depressing of the community soil block. Functionally it is replaced by the litter block of soil macrofauna, which is represented by highly mobile species that are able to recolonize microsites with temporary decrease of anthropogenic impact. Thus, the ecomorphic structure of the soil macrofauna community has high potential for application in the system of environmental impact assessment tools.

\section{References}

Adhikari, D., Tiwary, R., Singh, P. P., Upadhaya, K., Singh, B., Haridasan, K. E. ... Barik, S. K. (2019). Ecological niche modeling as a cumulative environmental impact assessment tool for biodiversity assessment and conservation planning: A case study of critically endangered plant Lagerstroemia minuticarpa in the Indian Eastern Himalaya. Journal of Environmental Management, 243, 299-307. doi: 10.1016/j.jenvman.2019.05.036

Andrusevich, K. V., Zhukov, A. V., \& Kunah, O. N. (2014). Ecomorphic organisation of the mesopedobionts community as the basis of the anthropogenic soils zoological diagnostic. The Journal of V. N.Karazin Kharkiv National University. Biology, 1126(22), 89-97.

Bartelheimer, M., \& Poschlod, P. (2014). The response of grassland species to nitrate versus ammonium coincides with their pH optima. Journal of Vegetation Science, 25(3), 760-770. doi: $10.1111 /$ jvs. 12124

Belgard, A. L. (1950). Forest vegetation of South-Eeast part of the Ukraine. Kiev University Press, Kiev (in Russian).

Belgard, A. L. (1971). Steppe forestry. Forestry industry, Moscow (in Russian).

Bernhardt-Römermann, M., Römermann, C., Nuske, R., Parth, A., Klotz, S., Schmidt, W., \& Stadler, J. (2008). On the identification of the most suitable traits for plant functional trait analyses. Oikos, 117(10), 1533-1541. doi: 10.1111/j.00301299.2008.16776.x

Bigard, C., Pioch, S., \& Thompson, J. D. (2017). The inclusion of biodiversity in environmental impact assessment: Policy-related progress limited by gaps and semantic confusion. Journal of Environmental Management, 200, 35-45. doi: 10.1016/j.jenvman.2017.05.057

Caliñ̃ski, T., \& Harabasz, J. (1974). A Dendrite Method Foe Cluster Analysis. Communications in Statistics, 3(1), 1-27. doi: 10.1080/03610927408827101

Dias, A. M. da S., Fonseca, A., \& Paglia, A. P. (2017). Biodiversity monitoring in the environmental impact assessment of mining projects: a (persistent) waste of time and money? Perspectives in Ecology and Conservation, 15(3), 206-208. doi: 10.1016/j. pecon.2017.06.001

Doledec, S., Chessel, D., \& Gimaret-Carpentier, C. (2000). Niche Separation in Community Analysis: A New Method. Ecology, 81(10), 2914. doi: $10.2307 / 177351$ 
Dolédec, S., Chessel, D., Ter Braak, C. J. F., \& Champely, S. (1996). Matching species traits to environmental variables: A new three-table ordination method. Environmental and Ecological Statistics, 3(2), 143-166. doi: 10.1007/BF02427859

Dray, S., \& Legendre, P. (2008). Testing the species traits environment relationships: The fourth-corner problem revisited. Ecology, 89(12), 3400-3412. doi: 10.1890/08-0349.1

Dray, S., Pettorelli, N., \& Chessel, D. (2002). Matching data sets from two different spatial samples. Journal of Vegetation Science, 13(6), 867-874. doi: 10.1111/j.1654-1103.2002.tb02116.x

Faly, L. I., Kolombar, T. M., Prokopenko, E. V., Pakhomov, O. Y., \& Brygadyrenko, V. V. (2017). Structure of litter macrofauna communities in poplar plantations in an urban ecosystem in Ukraine. Biosystems Diversity, 25(1), 29-38. doi: 10.15421/011705

Gardiner, M. M., Burkman, C. E., \& Prajzner, S. P. (2013). The Value of Urban Vacant Land to Support Arthropod Biodiversity and Ecosystem Services. Environmental Entomology, 42(6), 1123-1136. doi: 10.1603/en12275

Gilarov, M. S. (1965). Zoological methods of the soils diagnostic. Nauka, Moscow (in Russian).

Gritsan, Y. I., Kunakh, O. M., Dubinina, J. J., Kotsun, V. I., \& Tkalich, Y. I. (2019). The catena aspect of the landscape diversity of the "Dnipro-Orilsky" natural reserve. Journal of Geology, Geography and Geoecology, 28(3), 417-431. 10.15421/111939

Horsák, M. (2006). Mollusc community patterns and species response curves along a mineral richness gradient: A case study in fens. Journal of Biogeography, 33(1), 98-107. doi: 10.1111/j.1365-2699.2005.01359.x

Karpachevsky, L. O. (2005). Ecological soil science. GEOS, Moscow (in Russian).

Kolombar, T., Pakhomov, O., \& Zhukov, O. (2014). The role of pedoturbation activity of great mole rat (Spalax microphthalmus) in determining the structure of the soil cover. Scientific Journal "Visnyk of L'viv University". Biological Series, 64, 219-225.

Kuit, S. H., Ponnampalam, L. S., Ng, J. E., Chong, V. C., \& Then, A. Y. H. (2019). Distribution and habitat characteristics of three sympatric cetacean species in the coastal waters of Matang, Perak, Peninsular Malaysia. Aquatic Conservation: Marine and Freshwater Ecosystems, 29(10), 1681-1696. doi: 10.1002/ aqc. 3121

Kunah, O. M., Pakhomov, O. Y., Zymaroieva, A. A., Demchuk, N. I., Skupskyi, R. M., Bezuhla, L. S., \& Vladyka, Y. P. (2018). Agroeconomic and agroecological aspects of spatial variation of rye (Secale cereale) yields within Polesia and the Forest-Steppe zone of Ukraine: The usage of geographically weighted principal components analysis. Biosystems Diversity, 26(4), 276285. doi: $10.15421 / 011842$

Kunah, O. M., \& Papka, O. S. (2016). Ecogeographical determinants of the ecological niche of the common milkweed (Asclepias syriaca) on the basis of indices of remote sensing of land images. Visnyk of Dnipropetrovsk University. Biology, Ecology, 24(1), 78-86. doi: 10.15421/011609

Kunah, O. N. (2016). Functional and spatial structure of the urbotechnozem mesopedobiont community. Visnyk of Dnipropetrovsk University. Biology, Ecology, 24(2), 473-483. doi: 10.15421/011664

Kunakh, O. M., Yorkina, N. V., Zhukov, O. V., Turovtseva, N. M., Bredikhina, Y. L., \& Logvina-Byk, T. A. (2020). Recreation and terrain effect on the spatial variation of the apparent soil electrical conductivity in an urban park. Biosystems Diversity, 28(1), 3-8. doi: 10.15421/012001

Larsen, T., Hansen, T., \& Dierking, J. (2020). Characterizing niche differentiation among marine consumers with amino acid $813 \mathrm{C}$ fingerprinting. Ecology and Evolution, 10(14), 7768-7782. 10.1002/ece 3.6502

Marcotullio, P. J., Braimoh, A. K., \& Onishi, T. (2008). The impact of urbanization on soils. In A. K. Braimoh \& P. L. G. Vlek (Eds.), Land Use and Soil Resources (pp. 201-250). Springer,
Dordrecht. doi: $10.1007 / 978-1-4020-6778-510$

Maslikova, E. P. (2018). Phytoindication spatio-temporal structures tehnozemov and endogenous mechanisms of sustainable functioning of anthropogenic soil-like bodies. Agrology, 1(3), 273-280. doi: $10.32819 / 2617-6106.2018 .13006$

Maslikova, K. P. (2018). Ecomorphic structure of the soil macrofauna communities of technosols of the Nikopol Manganese Ore Basin. Biosystems Diversity, 26(2), 85-91. doi: $10.15421 / 011813$

Medvedev, V. V. (2009). Soil penetration resistance and penetrographs in studies of tillage technologies. Eurasian Soil Science, 42(3), 299-309. doi: 10.1134/S1064229309030077

Minden, V., Andratschke, S., Spalke, J., Timmermann, H., \& Kleyer, M. (2012). Plant trait-environment relationships in salt marshes: Deviations from predictions by ecological concepts. Perspectives in Plant Ecology, Evolution and Systematics, 14(3), 183192. doi: $10.1016 /$ j.ppees.2012.01.002

Moura, G. S., \& Franzener, G. (2017). Biodiversity of nematodes biological indicators of soil quality in the agroecosystems. Arquivos Do Instituto Biológico, 84(0). doi: 10.1590/18081657000142015

Mustafa, M. G., Khan, A. K. M. F., \& Mohsin, S. M. (2017). Community-based Resource Management Approaches Adopted in the Three Tributaries of River Surma, North-East Bangladesh. Journal of Fisheries and Aquatic Science, 12(2), 54-63. doi: $\underline{10.3923 / \text { jfas. } 2017.54 .63}$

Myers, S. S., \& Patz, J. A. (2009). Emerging Threats to Human Health from Global Environmental Change. Annual Review of Environment and Resources, 34(1), 223-252. doi: 10.1146/annurev.environ.033108.102650

Nita, A. (2019). Empowering impact assessments knowledge and international research collaboration - A bibliometric analysis of Environmental Impact Assessment Review journal. Environmental Impact Assessment Review, 78, 106283. doi: 10.1016/j. eiar.2019.106283

Ochoa, V., \& Urbina-Cardona, N. (2017). Tools for spatially modeling ecosystem services: Publication trends, conceptual reflections and future challenges. Ecosystem Services, 26, 155-169. doi: 10.1016/j.ecoser.2017.06.011

Pecchi, M., Marchi, M., Burton, V., Giannetti, F., Moriondo, M., Bernetti, I., Bindi, M., \& Chirici, G. (2019). Species distribution modelling to support forest management. A literature review. Ecological Modelling, 411, 108817. doi: 10.1016/j.ecolmodel.2019.108817

Pennisi, B. V., \& van Iersel, M. (2002). 3 ways to measure medium EC. GMPro, 22(1), 46-48.

Roa-Fuentes, C. A., \& Casatti, L. (2017). Influence of environmental features at multiple scales and spatial structure on stream fish communities in a tropical agricultural region. Journal of Freshwater Ecology, 32(1), 281-295. doi: $\underline{10.1080 / 02705060.2017 .1287129}$

Rosas, Y. M., Peri, P. L., Lencinas, M. V., \& Martínez Pastur, G. (2019). Potential biodiversity map of understory plants for Nothofagus forests in Southern Patagonia: Analyses of landscape, ecological niche and conservation values. Science of The Total Environment, 682, 301-309. doi: 10.1016/j.scitotenv.2019.05.179

Safaei, M., Tarkesh, M., Bashari, H., \& Bassiri, M. (2018). Modeling potential habitat of Astragalus verus Olivier for conservation decisions: A comparison of three correlative models. Flora, 242, 61-69. doi: 10.1016/j.flora.2018.03.001

Seebacher, D., Dirnböck, T., Dullinger, S., \& Karrer, G. (2012). Small-scale variation of plant traits in a temperate forest understorey in relation to environmental conditions and disturbance. Stapfia, 97, 153-168.

Smagin, A. V., Azovtseva, N. A., Smagina, M. V., Stepanov, A. L., Myagkova, A. D., \& Kurbatova, A. S. (2006). Criteria and methods to assess the ecological status of soils in relation to the 
landscaping of urban territories. Eurasian Soil Science, 39(5), 539-551. doi: 10.1134/S1064229306050115

Smagin, A. V., Kol'tsov, I. N., Pepelov, I. L., Kirichenko, A. V., Sadovnikova, N. B., \& Kinzhaev, R. R. (2011). The physical state of finely dispersed soil-like systems with drilling sludge as an example. Eurasian Soil Science, 44(2), 163-172. doi: 10.1134/S1064229311020128

Smagin, A. V., Sadovnikova, N. B., Kirichenko, A. V., Egorov, Y. V., Vityazev, V. G., \& Bashina, A. S. (2018). Dependence of the Osmotic Pressure and Electrical Conductivity of Soil Solutions on the Soil Water Content. Eurasian Soil Science, 51(12), 1462-1473. doi: 10.1134/S1064229318120128

Sousa, P., Gomes, D., \& Formigo, N. (2020). Ecosystem services in environmental impact assessment. Energy Reports, 6, 466-471. doi: 10.1016/j.egyr.2019.09.009

Tarasov, V. V. (2012). Flora of Dnipropetrovsk and Zaporizhia regions. Lira, Dnipropetrovsk (in Ukranian).

Thuiller, W., Lavorel, S., Midgley, G., Lavergne, S., \& Rebelo, T. (2004). Relating plant traits and species distributions along bioclimatic gradients for 88 Leucadendron taxa. Ecology, 85(6), 1688-1699. doi: 10.1890/03-0148

Yorkina, Nadia, Zhukov, O., \& Chromysheva, O. (2019). Potential possibilities of soil mesofauna usage for biodiagnostics of soil contamination by heavy metals. Ekologia Bratislava, 38(1), 1-10. doi: 10.2478/eko-2019-0001

Yorkina, N. V., Kunakh, O. M., \& Budakova, V. S. (2019). Ecological niche packing and spatial organisation of the urban park macrofauna comminity. Agrology, 2(4), 209-218. doi: $10.32819 / 019030$

Zadorozhnaya, G. A., Andrusevych, K. V., \& Zhukov, O. V. (2018). Soil heterogeneity after recultivation: Ecological aspect. Folia Oecologica, 45(1), 46-52. doi: 10.2478/foecol-2018-0005

Zhukov, O., \& Maslikova, K. (2018). The dependence of the technosols models functional properties from the primary stratigraphy designs. Journal of Geology, Geography and Geoecology, 27(2), 399-407. doi: 10.15421/111864

Zhukov, O. V., Zadorozhna, G. O., Maslikova, K. P., Andrusevych, K. V., \& Lyadskaya, I. V. (2017). Tehnosols Ecology. Zhurfond, Dnipro.

Zhukov, A. V., Kunah, O. N., Prokopenko, E. V., \& Konovalova, T. M. (2011). The pedoturbation activity of the mole rats (Spalax microphthalmus) as a factor og the spatial organization of the spider (Aranei). News of Dnipropetrovsk State Agrarian and Economic University, 6, 28-35.

Zhukov, A. V., Maslikova, K. P., \& Kovalenko, D. V. (2018). Dynamics of the regulatory ecosystem service following the technogenic soil forming process in Nikopol manganese ore basin. Naukovì Dopovìdì Nacìonal'nogo Unìversitetu Bìoresursiv ì Prirodokoristuvannâ Ukraïni, 2018(6). doi: 10.31548/dopovidi2018.06.005

Zhukov, A. V., \& Zadorozhnaya, G. A. (2016). Spatio-temporal dynamics of the penetration resistance of recultivated soils formed after open cast mining. Visnyk of Dnipropetrovsk University. Biology, Ecology, 24(2), 324-331. doi: 10.15421/011642

Zhukov, O. V. (2009). The ecomorphic analysis of the soil animals consortia. Svidler press, Dnipropetrovsk (in Ukranian).

Zhukov, O. V., Kovalenko, D. V., Kramarenko, S. S., \& Kramarenko, A. S. (2019). Analysis of the spatial distribution of the ecological niche of the land snail Brephulopsis cylindrica (Stylommatophora, Enidae) in technosols. Biosystems Diversity, 27(1), 62-68. doi: 10.15421/011910

Zhukov, O. V., Kunah, O. N., \& Novikova, V. A. (2016). The functional organisation of the mesopedobionts community of sod pinewood soils on arena of the river Dnepr. Visnyk of Dnipropetrovsk University. Biology, Ecology, 24(1), 26-39. doi: $\underline{10.15421 / 011604}$

Zhukov, O. V., Kunakh, O. M., Taran, V. O., \& Lebedinska, M. M. (2016). Spatial variability of soils electrical conductivity within arena of the river dnepr valley (territory of the natural reserve "Dniprovsko-Orilsky"). Biological Bulletin of Bogdan Chmelnitskiy Melitopol State Pedagogical University, 6(2), 129-157. doi: $10.15421 / 201646$

Zhukov, Oleksandr V., Kunah, O. M., Dubinina, Y. Y., Fedushko, M. P., Kotsun, V. I., Zhukova, Y. O., \& Potapenko, O. V. (2019). Tree canopy affects soil macrofauna spatial patterns on broadAnd meso-scale levels in an Eastern European poplar-willow forest in the floodplain of the River Dnipro. Folia Oecologica, 46(2), 101-114. doi: 10.2478/foecol-2019-0013

Zhukov, Olexandr V., Bondarev, D. L., Yermak, Y. I., \& Fedushko, M. P. (2019). Effects of temperature patterns on the spawining phenology and niche overlap of fish assemblages in the water bodies of the Dnipro River basin. Ecologica Montenegrina, 22, 177-203. 